Editorial

\title{
Our common future - 25 years later: Sustainable development WHATs, HOWs and WHOs of energy, water and environment systems
}

The eighties of the previous century mark a point in the history when awareness was growing about the risk for overstepping global environmental limits, the need to adapt the use of natural resources to the long-term carrying capacity of the planet, as well as about the fact that unequal opportunity and unequal distribution of resources were at the heart of the problem. The predominant thinking at that time was: It is either the environment you can protect or it is the economy you can develop, but not both at the same time.

The Brundtland Commission faced this setting with a new political idea: A sustainable development is how it is recommended to face the challenge of meeting the needs of present generations without compromising the ability of future generations to meet their needs. This political concept includes equity and justice, within and between generations, and clear idea of developing a shared understanding of the long-term goals for human life on earth, new governance instruments and collective action.

Twenty-five years later, UNFCCC (United Nations Framework Convention on Climate Change) Parties are negotiating the new, potentially legally binding, treaty replacing the Kyoto Protocol, to be signed by the industrialized and developing countries by 2015 and put into effect by 2020 . On its way towards carbon free power sector in 2050 [1], the EU is pondering 2030 ambition level for GHG reductions in view of this treaty and how to support the progress towards a competitive economy and a secure energy system [2].

In celebration of the 25th anniversary of the "Report on Our Common Future" - the most important point in turning the world towards a more sustainable future, the 7th SDEWES Conference was aimed at looking into sustainable development WHATs, HOWs and WHOs of energy, water and environment systems and providing responsive scientific support to the emerging international, European, regional and national challenges. Being held in Ohrid, the pearl of Macedonia and another UNESCO world heritage site, this was the first in the series of SDEWES conferences organized outside Dubrovnik, and served as a venue for more than 200 world-wide scientists and specialists and those interested in learning about the sustainability of development, coming from 45 countries to present research progress and to discuss the state of the art, the future directions and priorities in the various areas of sustainable development.

This special issue includes 26 selected SDEWES papers which cover a variety of energy issues, starting from biomass, wind and solar, coal, synthetic fuels, through storage and power system operation at energy supply side, as well as, buildings, district heating, transport, heat exchangers and energy efficiency at demand side.
Specifically, optimal utilization of various forms of biomass as energy resources was addressed in Lam et al. [3], proposing a green strategy for systematic design of waste-to-energy supply chain which includes efficient resources management and reduction of carbon footprint. Furthermore, environmental and energy performance of combined cooling heating and power systems based on biomass combustion were analysed and compared to conventional generation in Maraver et al. [4]

As far as solar and wind energy are concerned, Ban et al. [5] conducted a mapping of the high altitude wind energy in Southeast Europe, while Bjelić et al. [6] studied the potential impacts of an increased wind power penetration in the case of energy system of Serbia. Calling it a looming revolution, Haas et al. [7] explained how the photovoltaics will change electricity markets in Europe. A specific application of photovoltaics was also considered (Uche et al. [8]), testing a small batch electrodialysis unit fed by a photovoltaic array used to desalt brackish water.

As to the coal, cases of retrofitting of the existing power plants were presented, such as modifications of control systems (Mikulandrić et al. [9]) and carbon capture upgrades (Zhu \& Fan [10]).

Essential for matching the demand and meeting the criteria of a $100 \%$ renewable energy system in transport sector, potential pathways for producing synthetic fuels were identified in Ridjan et al. [11], with a specific focus on solid oxide electrolyser cells combined with the recycling of $\mathrm{CO}_{2}$.

The energy storage technologies were considered in light of their capacity to manage the variable renewable generation and to align non-dispatchable renewable energy generation with load demands. Hence, Díaz Lobera \& Foley [12] examined the impacts of a compressed air energy storage facility in a pool based wholesale electricity market in a power system with a large renewable energy portfolio, while Marino et al. [13] analysed energy, economic and environmental aspects of a self-sufficient system for energy production in buildings which uses hydrogen for energy storage.

At last, to the end of power system operation, Scharff et al. [14] quantified the value of shifting of larger parts of the balancing responsibility from the transmission system operator to the power generating companies, with a case study based on the Nordic electricity market. In addition, Kanevce et al. [15] modelled the longterm dynamical evolution of Southeast European power transmission system, looking at the system as an evolving grid, which is continually upgrading in order to satisfy the increasing load demand and certain reliability requirements. 
Buildings remained the topical issue at the energy demand side. Annunziata et al. [16] considered the pathways towards nearly zero buildings in Europe, while Ó Broin et al. [17] examined the role of improved efficiency for energy savings in EU 27 buildings.

An approach for minimization of the capital costs and energy consumption in a district heating network is presented by Pirouti et al. [18], using a case study based on a district heating network in South Wales, UK.

Scarpellini et al. [19] propose a methodology for measuring ecoinnovation in the transport sector, including analyses of the employment potential of the sustainable transport sector. Transport sector was dealt with also in Puksec et al. [20], where a bottom-up model was created for long term forecasting of energy demand and used on the case of Croatia. Furthermore, in Dedinec et al. [21], the analytical framework for assessment of climate change mitigation potential of transport sector in developing countries was adapted in order to incorporate the expected vehicle fleet increase with used vehicles and applied to assess the climate change mitigation potential of the Macedonian transport sector.

A number of papers addressed the heat exchangers, focussing on optimization approach for improving energy recovery in retrofitting heat exchanger network (Pan et al. [22]), influence of plate corrugations geometry (Arsenyeva et al. [23]), heat transfer intensification for shell and tube heat exchangers (Pan et al. [24]), optimization of entire life economy of heat exchanger network (Nemet et al. [25]), as well as on simultaneous synthesis of process water and heat exchanger networks (Ahmetović \& Kravanja [26]).

The issue of energy efficiency was also tackled through consideration of instruments for influencing the behaviour of electric utilities in the market, corresponding to both impositions and stimuli, such as defining savings targets or decoupling profits from energy sales (Sousa et al. [27]).

Finally, Ortas \& Moneva [28] measured the financial performance of 21 primary Clean Techs equity indexes, covering the primary energy markets worldwide.

\section{Conclusions and acknowledgements}

This Special issue, devoted to energy at the Conference on Sustainable Development of Energy Water and Environmental Systems - SDEWES 2012, provided an overview of several topics related to sustainable development. The Guest editors believe that the selected papers and addressed issues will be of interest to the readers of ENERGY journal.

The Guest editors would like to thank all the reviewers who have made most valuable contribution by reviewing, commenting and advising authors. Special thanks should go to the administration staff of the ENERGY journal for the excellent support.

\section{References}

[1] European Commission. Energy roadmap 2050. COM (2011) 885 final of 15 December, 2011.

[2] European Commission. Green paper, a 2030 framework for climate and energy policies. COM (2013) 169 final of 27 March, 2013.

[3] Loong Lam Hon, Wendy PQ Ng, Rex TL Ng, Ern Huay Ng, Abdul Aziz Mustafa K, Denny KS Ng. Green strategy for sustainable waste-to-energy supply chain. Energy. http://dx.doi.org/10.1016/j.energy.2013.01.032; 2013.

[4] Maraver Daniel, Sin Ana, Sebastián Fernando, Royo Javier. Environmental assessment of CCHP (combined cooling heating and power) systems based on biomass combustion in comparison to conventional generation. Energy. http://dx.doi.org/10.1016/j.energy.2013.02.014; 2013.

[5] Ban Marko, Perković Luka, Duić Neven, Penedo Ricardo. Estimating the spatial distribution of high altitude wind energy potential in Southeast Europe. Energy. http://dx.doi.org/10.1016/j.energy.2012.12.045; 2013.

[6] Batas Bjelić Ilija, Rajaković Nikola, Cosić Boris, Duić Neven. Increasing wind power penetration into the existing Serbian energy system. Energy. http:// dx.doi.org/10.1016/j.energy.2013.03.043; 2013.
[7] Haas Reinhard, Lettner Georg, Auer Hans, Duić Neven. The looming revolution: how photovoltaics will change electricity markets in Europe fundamentally. Energy. http://dx.doi.org/10.1016/j.energy.2013.04.034; 2013.

[8] Uche J, Círez F, Bayod AA, Martínez A. On-grid and off-grid batch-ED (electrodialysis) process: simulation and experimental tests. Energy. http://dx.doi.org/ 10.1016/j.energy.2013.02.056; 2013.

[9] Mikulandrić Robert, Lončar Dražen, Cvetinović Dejan, Spiridon Gabriel. Improvement of existing coal fired thermal power plants performance by control systems modifications. Energy. http://dx.doi.org/10.1016/j.energy.2013. 02.033; 2013.

[10] Zhu Lei, Fan Ying. Modelling the investment in carbon capture retrofits of pulverized coal-fired plants. Energy. http://dx.doi.org/10.1016/j.energy.2013.03. $072 ; 2013$.

[11] Ridjan Iva, Mathiesen Brian Vad, Connolly David, Duić Neven. The feasibility of synthetic fuels in renewable energy systems. Energy. http://dx.doi.org/10. 1016/j.energy.2013.01.046; 2013.

[12] Díaz Lobera I, Foley A. Impacts of compressed air energy storage plant on an electricity market with a large renewable energy portfolio. Energy. http://dx. doi.org/10.1016/j.energy.2013.04.031; 2013.

[13] Marino C, Nucara A, Pietrafesa M, Pudano A. An energy self-sufficient public building using integrated renewable sources and hydrogen storage. Energy. http://dx.doi.org/10.1016/j.energy.2013.01.053; 2013.

[14] Scharff Richard, Amelin Mikael, Söder Lennart. Approaching wind power forecast deviations with internal ex-ante self-balancing. Energy. http://dx.doi.org/ 10.1016/j.energy.2013.03.033; 2013.

[15] Kanevce Aleksandra, Mishkovski Igor, Kocarev Ljupco. Modeling long-term dynamical evolution of Southeast European power transmission system. Energy. http://dx.doi.org/10.1016/j.energy.2013.03.003; 2013.

[16] Annunziata Eleonora, Frey Marco, Rizzi Francesco. Towards nearly zeroenergy buildings: the state-of-art of national regulations in Europe. Energy. http://dx.doi.org/10.1016/j.energy.2012.11.049; 2013.

[17] Ó Broin Eoin, Mata Érika, Göransson Anders, Johnsson Filip. The effect of improved efficiency on energy savings in EU 27 buildings. Energy. http://dx. doi.org/10.1016/j.energy.2013.01.016; 2013.

[18] Pirouti Marouf, Bagdanavicius Audrius, Ekanayake Janaka, Wu Jianzhong, Jenkins Nick. Energy consumption and economic analyses of a district heating network. Energy. http://dx.doi.org/10.1016/j.energy.2013.01.065; 2013.

[19] Scarpellini S, Valero A, Llera E, Aranda A. Multicriteria analysis for the assessment of energy innovations in the transport sector. Energy. http://dx.doi.org/ 10.1016/j.energy.2012.12.004; 2013.

[20] Puksec T, Krajačić G, Lulić Z, Mathiesen BV, Duic N. Forecasting long-tem energy demand of Croatian transport sector. Energy. http://dx.doi.org/10.1016/j. energy.2013.04.071; 2013.

[21] Dedinec A, Markovska N, Taseska V, Duic N, Kanevce G. Assessment of climate change mitigation potential of the Macedonian transport sector. Energy. http://dx.doi.org/10.1016/j.energy.2013.05.011; 2013.

[22] Pan Ming, Smith Robin, Bulatov Igor. A novel optimization approach of improving energy recovery in retrofitting heat exchanger network with exchanger details. Energy. http://dx.doi.org/10.1016/j.energy.2012.10.056; 2013.

[23] Arsenyeva O, Kapustenko P, Tovazhnyanskyy L, Khavin G. The influence of plate corrugations geometry on plate heat exchanger performance in specified process conditions. Energy. http://dx.doi.org/10.1016/j.energy.2012.12. 034; 2013.

[24] Pan Ming, Jamaliniya Sara, Smith Robin, Bulatov Igor, Gough Martin Higley Tom, et al. New insights to implement heat transfer intensification for shell and tube heat exchangers. Energy. http://dx.doi.org/10.1016/j. energy.2013.01.017; 2013.

[25] Nemet Andreja, Klemeš Jiří Jaromír, Kravanja Zdravko. Optimising entire lifetime economy of heat exchanger networks. Energy. http://dx.doi.org/10.1016/ j.energy.2013.02.046; 2013.

[26] Ahmetović Elvis, Kravanja Zdravko. Simultaneous synthesis of process water and heat exchanger networks. Energy. http://dx.doi.org/10.1016/j.energy. 2013.02.061; 2013.

[27] Sousa José Luís, Martins António Gomes, Jorge Humberto. Dealing with the paradox of energy efficiency promotion by electric utilities. Energy. http:// dx.doi.org/10.1016/j.energy.2013.02.040; 2013.

[28] Ortas Eduardo, Moneva José M. The clean techs equity indexes at stake: risk and return dynamics analysis. Energy. http://dx.doi.org/10.1016/j.energy. 2013.03.046; 2013.

Natasa Markovska

Research Center for Energy, Informatics and Materials, Macedonian Academy of Sciences and Arts (ICEIM-MANU), Krste Misirkov 2, 1000 Skopje, Macedonia

E-mail address: natasa@manu.edu.mk

Neven Duić*, Zvonimir Guzović

Department of Energy, Power Engineering and Environment, University of Zagreb, Faculty of Mechanical Engineering and Naval Architecture, Ivana Lučića 5, 10002 Zagreb, Croatia 
Brian Vad Mathiesen, Henrik Lund Department of Development and Planning, Aalborg University, A.C. Meyers Vænge 15, DK-2450 Copenhagen SV, Denmark E-mail addresses: bvm@plan.aau.dk (B.V. Mathiesen);

lund@plan.aau.dk (H. Lund)
* Corresponding author. E-mail addresses: neven.duic@fsb.hr (N. Duić); zvonimir.guzovic@fsb.hr (Z. Guzović) 